\title{
Production and Characterization of Collagenase by Penicillium sp. UCP 1286 Isolated From Caatinga Soil
}

\author{
Maria Carolina de Albuquerque Wanderley ${ }^{1,2}$, Jose Manoel Wanderley Duarte Neto ${ }^{2}$, Carolina de Albuquerque Lima ${ }^{3}$, \\ Sara Isabel da Cruz Silverio ${ }^{4}$, Jose Luiz de Lima Filho ${ }^{2}$, Jose Antonio Couto Teixeira ${ }^{4}$, Ana Lucia Figueiredo Porto ${ }^{5 *}$ \\ ${ }^{1}$ Department of Molecular Sciences, Federal Rural University of Pernambuco (UFRPE), Av. Dom Manoel de Medeiros, s/n, 52171 -900, Recife, PE, Brazil. \\ ${ }^{2}$ Laboratory of Immunopathology Keizo Asami (LIKA), Federal University of Pernambuco, Av. Prof. Moraes Lins do Rego, s/n, 50670-901, Recife, PE, \\ Brazil. ${ }^{3}$ Faculty of Science, Education and Technology of Garanhuns, University of Pernambuco-UPE, Av. Capitão Pedro Rodrigues, $\mathrm{n}^{\circ} 105$, Garanhuns, \\ PE, Brazil. ${ }^{4}$ Centre of Biological Engineering, University of Minho, Campus Gualtar, 4710-057, Braga, Portugal. ${ }^{5}$ Department of Morphology and Animal \\ Physiology, Federal Rural University of Pernambuco, Av. Dom Manoel de Medeiros, s/n, 52171-900, Recife, PE, Brazil.
}

\begin{tabular}{|c|c|}
\hline ARTICLE INFO & ABSTRACT \\
\hline $\begin{array}{l}\text { Article history: } \\
\text { Received on: } 14 / 06 / 2016 \\
\text { Revised on: } 14 / 07 / 2016 \\
\text { Accepted on: } 30 / 07 / 2016 \\
\text { Available online: } 26 / 08 / 2016\end{array}$ & $\begin{array}{l}\text { A new Penicillium sp. strain isolated from the soil of Caatinga, a Brazilian Biome (UCP 1286) was selected for } \\
\text { collagenase production. Fermentation system allowing obtention of collagenolytic activity about } 2.7 \text { times higher } \\
\text { than existing data, with the highest values of collagenolytic and specific activity ( } 379.80 \mathrm{U} / \mathrm{mL}, 1460.77 \mathrm{U} / \mathrm{mg} \text {, } \\
\text { respectively), after } 126 \text { hours. Applying a factorial design, enzyme production was increased by about } 65 \% \\
\text { compared to the preliminary results. The factorial design demonstrated the existence of two factors with }\end{array}$ \\
\hline $\begin{array}{l}\text { Key words: } \\
\text { Collagenolytic; Enzymes; } \\
\text { Factorial Design; } \\
\text { Fermentation; Filamentous } \\
\text { Fungi; Specificity. }\end{array}$ & $\begin{array}{l}\text { statistical significance on the production of the enzyme: } \mathrm{pH} \text { and temperature, both with negative effects. Enzyme } \\
\text { was found to be more active at } \mathrm{pH} 9.0 \text { and } 37{ }^{\circ} \mathrm{C} \text {, and also to be very stable in comparison with the collagenase } \\
\text { produced by other microorganisms. The enzyme seems to belong to collagenolytic serine proteases family. } \\
\text { Concerning the substrate specificity, it was observed that the highest enzyme activity corresponds to azocoll, } \\
\text { there was no relevant activity on azocasein and the enzyme showed to be more specific to type } \mathrm{V} \text { collagen and } \\
\text { gelatin than the commercial colagenase produced by Clostridium histolyticum. Major band observed at } \\
\text { electrophoresis was approximately } 37 \mathrm{kDa} \text {. Zymogram analysis confirmed the collagenolytic activity. All data } \\
\text { indicates this enzyme as promising biotechnology product. }\end{array}$ \\
\hline
\end{tabular}

\section{INTRODUCTION}

Collagen is the major fibrous element of skin, bones, tendons, cartilage, blood vessels and teeth found in all animals $[1,2]$. Collagen is found in connective tissues, making up approximately $30 \%$ of the protein in human body [3,4]. Because of the rigid structure of collagen (three helically wound polypeptide fibrils) its degradation is restricted to a few proteases [2]. Collagenases are specific enzymes that can hydrolyze both

\footnotetext{
* Corresponding Author

Department of Morphology and Animal Physiology, Federal Rural University of Pernambuco, Av. Dom Manoel de Medeiros, s/n, 52171 900, Recife, PE, Brazil.Email: analuporto@yahoo.com.br,

Telephone number: +558133206391 , Fax number: +518121268485
}

native and denatured collagens $[5,6]$. These enzymes can degrade native triple helix of collagen to small fragments and play an important role in connective tissue metabolism [7,8]. Collagenolytic enzymes are a kind of proteases that are related to various physiological and pathological processes and have several applications in industry, medicine and biotechnology [6,9-11]. With biotechnology accelerated growth, applications of proteases have expanded to new areas such as clinical, medicinal and analytical chemistry [12]. Among various sources of proteases, those produced by microorganisms play an important role in biotechnological processes and are used with increasing frequency, as large amounts of these enzymes can be produced quickly and at low cost [13]. Search for microbial collagenases has been increasing due to their wide application, as they are able to cleave collagen helix at multiple sites, while mammalian collagenases cleave at a single site $[1,14]$. 
Microorganisms are preferred as source of collagenolytic enzymes due to their biochemical diversity and susceptibility to genetic manipulation [15]. Furthermore, microbial collagenases are quite versatile, possess broad substrate specificities and are able to hydrolyze both water-insoluble native collagens and watersoluble denatured collagens [16-18].

The extracellular production of fungi collagenases makes particularly easy its recovery after the end of fermentation [19]. Studies have reported the biosynthesis of collagenases by fungi belonging to the different genera, such as Aspergillus, Cladosporium, Alternaria, Penicillium [8,20-22], Candida [23], Microsporum [24] and Rhizoctonia [14]. Species of Penicillium genus have a higher biotechnological potential compared to other genera cited, both for production of proteases and other enzymes, as they have the capacity of growth in different culture conditions, using a wide variety of substrates as nutrients [25].

Caatinga is an exclusively Brazilian Biome, located in Northeast Brazil, with about one million square kilometers, mostly overlapping with semiarid region, inhabited by approximately 23 million people [26,27]. Soils are a rich environment for microorganisms and their characteristics affect directly microbiota [28]. The microbial diversity of Caatinga soils is still poorly studied, but this biome has severe climate conditions, such as high temperature, high UV exposure and long periods of drought which promote the presence of microorganisms with distinct taxonomic and functional composition in relation to other biomes [26,28].

The aim of this work was to report a new producer strain of collagenase, isolated from the soil Caatinga (Pernambuco Brazil), and determine the best conditions for the production of the enzyme using an inexpensive culture medium. Furthermore, collagenase was characterized under the most favorable conditions and a variety of substrates was tested, to study its specificity to azocasein and different forms of collagen.

\section{MATERIAL AND METHODS}

\subsection{Microorganism}

The Penicillium sp. strain (UCP 1286) isolated from Serra Talhada city soil, in Caatinga biome (Pernambuco - Brazil), were obtained from UCP - the Catholic University of Pernambuco Collection, UNICAP.

\subsection{Culture medium}

The maintenance medium used was malt extract agar containing: malt extract $(0.5 \%)$, peptone $(0.1 \%)$, glucose $(2 \%)$ agar $1.5(\%)$. The culture medium used for enzyme production is composed of: gelatin $(0.5 \% \mathrm{w} / \mathrm{v}), \mathrm{MgSO}_{4} \cdot 7 \mathrm{H}_{2} \mathrm{O}(0.025 \mathrm{w} / \mathrm{v})$, $\mathrm{K}_{2} \mathrm{HPO}_{4}(1.5 \mathrm{w} / \mathrm{v}), \mathrm{FeSO}_{4} \cdot 7 \mathrm{H}_{2} \mathrm{O}(0.015 \mathrm{w} / \mathrm{v}), \mathrm{CaCl}_{2}(0.025 \mathrm{w} / \mathrm{v})$ and mineral solution $(1 \% \mathrm{v} / \mathrm{v})$, according Lima et al. (2011b) modified. The mineral solution was prepared by adding, per 100 $\mathrm{mL}$ of distilled water, $100 \mathrm{mg} \mathrm{FeSO}_{4} \cdot 7 \mathrm{H}_{2} \mathrm{O}, 100 \mathrm{mg}$ $\mathrm{MnCl}_{2} \cdot 4 \mathrm{H}_{2} \mathrm{O}, 100 \mathrm{mg} \mathrm{ZnSO}_{4} \cdot \mathrm{H}_{2} \mathrm{O}$, and $100 \mathrm{mg} \mathrm{CaCl}_{2} \cdot \mathrm{H}_{2} \mathrm{O}$, and it was used $1 \%$ from total volume of fermentation. Both medium were sterilized in autoclave at $121^{\circ} \mathrm{C}$ for $15 \mathrm{~min}$.

\subsection{Kinetic of growth and collagenolytic enzyme production}

Inoculum spores were produced in maintenance medium plates containing a cell culture grown for 5 days at $28{ }^{\circ} \mathrm{C}$, and then suspended in $3 \mathrm{~mL}$ of a $0.9 \%$ (w/v) $\mathrm{NaCl}$ and $0.01 \%$ (v/v) Tween 80 solution, previously sterilized at $121{ }^{\circ} \mathrm{C}$ for $20 \mathrm{~min}$. After inoculation with a $150 \mu \mathrm{L}$ spores suspension $\left(10^{6}\right.$ spores $\left./ \mathrm{mL}\right)$, fermentation was carried out for 8 days at $28{ }^{\circ} \mathrm{C}$ and $150 \mathrm{rpm}$ in 1 L Erlenmeyer flasks containing $250 \mathrm{~mL}$ of the culture medium. At 6-hour intervals, $2 \mathrm{~mL}$ samples were taken for protein content and collagenolytic activity determination. Cotton caps were used to minimize water evaporation. The broth obtained at the end of fermentation was vacuum filtered through $0.45 \mu \mathrm{m}$-pore diameter nitrocellulose membranes to remove the mycelium.

\subsection{Screening of significant variables for collagenolytic enzyme production}

To evaluate the influence of the initial $\mathrm{pH}$, initial concentration of gelatin, temperature and agitation on extracellular collagenolytic enzyme production by Penicillium sp. UCP 1286 isolated from Caatinga soil, a $2^{4}$ factorial design was carried out at all combinations of levels given in Table 1.

Table 1: Factors levels used in $2^{4}$ design to investigate the production of collagenolytic enzyme by Penicillium sp. isolated from Caatinga soil

\begin{tabular}{llll}
\hline \multirow{2}{*}{\multicolumn{1}{c}{ Factors }} & \multicolumn{3}{c}{ Level } \\
\cline { 2 - 4 } & $\begin{array}{c}\text { Lowest } \\
(-\mathbf{1})\end{array}$ & $\begin{array}{c}\text { Central } \\
(\mathbf{0})\end{array}$ & $\begin{array}{c}\text { Highest } \\
(+\mathbf{+ 1})\end{array}$ \\
\hline $\mathrm{pH}$ & 6.0 & 7.0 & 8.0 \\
Gelatin concentration $(\%, \mathrm{w} / \mathrm{v})$ & 0.25 & 0.50 & 0.75 \\
Temperature $\left({ }^{\circ} \mathrm{C}\right)$ & 24 & 28 & 32 \\
Orbital agitation speed $(\mathrm{rpm})$ & 100 & 150 & 200 \\
\hline
\end{tabular}

The center point was performed in quadruplicate, to provide a variance estimate of pure experimental error responses. From this, it was predicated the effects of experimental errors and used to assess the significance of the effects and interactions of the independent variables - $\mathrm{pH}$, concentration of carbon and nitrogen source (gelatin), temperature and orbital agitation speed - on the production of collagenolytic enzyme. All statistical and graphical analyzes were performed with $95 \%$ confidence using the Statistica 8.0 software (StatSoft Inc., Tulsa, OK, USA).

\subsection{Azocoll assay for collagenolytic enzyme activity determination}

The Azo dye-impregnated collagen (Azocoll; Sigma Chemical Co., St Louis, MO) assay was carried out according to a modified version of the method developed by Chavira et al. [29]. Azocoll was washed and suspended in $0.05 \mathrm{M}$ Tris- $\mathrm{HCl}$ buffer $(\mathrm{pH}$ 7.2) containing $1 \mathrm{mM} \mathrm{CaCl} 2$ up to a final concentration of $0.5 \%$ (w/v). Subsequently, $150 \mu \mathrm{L}$ of cell-free filtrate and $150 \mu \mathrm{L}$ of buffer were mixed with $270 \mu \mathrm{L}$ of azocoll suspension in a $2.0-\mathrm{mL}$ reaction tube. The reaction tubes were incubated at $37{ }^{\circ} \mathrm{C}$ in a water bath under agitation. After $18 \mathrm{~h}$ of incubation, the samples were chilled in ice for $5 \mathrm{~min}$ to stop the reaction and centrifuged at $10,000 \times g$ and $4{ }^{\circ} \mathrm{C}$ for $20 \mathrm{~min}$ (model KR-20000T; Kubota Seisakusho, Tokyo, Japan). The absorbance of the supernatant was 
measured at $520 \mathrm{~nm}$ by a UV-Vis spectrophotometer (model B582; Micronal, São Paulo, Brazil). One unit of enzyme activity (U) was defined as the amount of enzyme, per millilitre, that led, after $18 \mathrm{~h}$ of incubation, to an absorbance increase of 0.1 at 520 $\mathrm{nm}$, because of the formation of azo dye-linked soluble peptides.

\subsection{Saline precipitation with ammonium sulfate}

Crude extract was placed in an ice bath and $\left(\mathrm{NH}_{4}\right)_{2} \mathrm{SO}_{4}$ was added, at different concentrations of saturation $(0-20 \%, 20-$ $40 \%, 40-60 \%, 60-80 \%$ and $80-90 \%$ ), with constant stirring for 2 hours. Precipitated protein was removed by centrifugation at $10.000 \mathrm{rpm}$, for $15 \mathrm{~min}$ at $4{ }^{\circ} \mathrm{C}$ and the supernatant was discarded. The precipitated protein was dissolved in $4 \mathrm{~mL}$ of $0.05 \mathrm{M}$ Tris- $\mathrm{HCl}$ buffer of $\mathrm{pH} 9.0$. The $60-80 \%$ was selected based on its specific collagenolytic activity. Ammonium sulfate was removed using dialysis.

\subsection{Protein and Biomass determination}

Protein concentration was determined by the method of Bradford [30] modified using the dye as "Coomassie Blue Bright G-250" to detect protein in enzymatic samples. The calibration curve was obtained from stock solutions of bovine serum albumin (BSA).

Total volume of fermentation flasks was filtered for biomass determination. Biomass was determined by the dry weight method using pre-weighted nitrocellulose membranes with 0.45 $\mu \mathrm{m}$-pore diameter, after drying at $80^{\circ} \mathrm{C}$ for $24 \mathrm{~h}$.

\subsection{Effects of pH and temperature on collagenolytic enzyme activity and stability}

To evaluate $\mathrm{pH}$ effect on collagenolytic enzyme activity, the $\mathrm{pH}$ of the reaction mixture containing $0.5 \%(\mathrm{w} / \mathrm{v})$ of azocoll was varied over the range $3.0 \sim 11.0$. The buffers used were 0.05 $\mathrm{M}$ citrate ( $\mathrm{pH} 3.0 \sim 6.0), 0.05 \mathrm{M}$ Tris- $\mathrm{HCl}(\mathrm{pH} 7.0 \sim 9.0)$, and 0.05 $\mathrm{M}$ carbonate-bicarbonate $(\mathrm{pH} 10.0 \sim 11.0)$. For stability tests, the culture filtrated was incubated at $4{ }^{\circ} \mathrm{C}$ (selected as a cold storage reference temperature at which the enzyme thermo inactivation is expected to be very low) in the above buffers at different $\mathrm{pH}$ values. The incubation time of samples varied from 1 to $24 \mathrm{~h}$.

An analogous study was done for the effect of temperature in the same azocoll-buffer solution. To determine optimum temperature for enzyme activity, the reaction mixture was incubated at the selected temperature (from 25 to $70{ }^{\circ} \mathrm{C}$ ), while for thermo stability tests the enzyme was pre-incubated for $15 \sim 180 \mathrm{~min}$ at the same temperatures.

The residual activity was calculated as the ratio between the enzymatic activity, observed at the end of each incubation run, and that at the beginning, and expressed as percentage (\%).

\subsection{Substrate specificity}

To test substrate specificity, the proteolytic activity of extracellular collagenolytic enzyme produced by Penicillium sp. UCP 1286 and commercial collagenase was also assayed on insoluble collagen (type I and type V), gelatin and azocasein.
Azocasein was used as comparison substrate to check on enzyme specificity.

The activity was assayed on insoluble collagen according to Endo et al. [31]. The standard reaction mixture, containing 25 mg collagen (type I and V, from bovine Achilles tendon) in $5 \mathrm{~mL}$ of $0.05 \mathrm{M}$ Tris- $\mathrm{HCl}$ buffer ( $\mathrm{pH} 7.0$ ), was incubated with $1 \mathrm{~mL}$ enzyme samples at $37^{\circ} \mathrm{C}$. The amount of free amino groups released was measured by the ninhydrin method of Rosen (1975). One activity unit (U) was defined as the number of $\mu$ mol of $\mathrm{L}$ leucine released as a result of the action of $1 \mathrm{~mL}$ culture filtrate containing collagenolytic enzyme, after $18 \mathrm{~h}$ at $37^{\circ} \mathrm{C}$.

Collagenolytic enzyme activity on gelatin was assayed by the method of Moore and Stein [33], slightly modified. Reaction was carried out at $37^{\circ} \mathrm{C}$ for $18 \mathrm{~h}$ after the addition of 0.1 $\mathrm{mL}$ of the enzyme solution to $1.0 \mathrm{~mL}$ of a solution containing 2 $\mathrm{mg}$ gelatin in $0.05 \mathrm{M}$ Tris- $\mathrm{HCl}$ buffer $(\mathrm{pH} 7.5)$. The reaction was stopped by the addition of $0.1 \mathrm{~mL}$ of $10 \%(\mathrm{w} / \mathrm{v})$ trichloroacetic acid. The medium was centrifuged at $10,000 \mathrm{x} \mathrm{g}$ for $10 \mathrm{~min}$. The supernatant $(0.2 \mathrm{~mL})$ was mixed with $0.5 \mathrm{~mL}$ of ninhydrin solution, heated at $100^{\circ} \mathrm{C}$ for $10 \mathrm{~min}$, cooled in ice water for $5 \mathrm{~min}$, and the mixture was then diluted with $2.5 \mathrm{~mL}$ of $50 \%(\mathrm{v} / \mathrm{v}) 1$ propanol. After centrifugation at $12,000 \times \mathrm{g}$ for $10 \mathrm{~min}$, the absorbance of the mixture was measured at $570 \mathrm{~nm}$. One unit (U) of enzyme activity was expressed as $\mu \mathrm{mol}$ of L-leucine equivalents released per min.

The enzyme activity on azocasein was determined according to Leighton et al. (1973), with $1 \%(w / v)$ azocasein in a $0.1 \mathrm{M}$ Tris- $\mathrm{HCl}$ buffer $(\mathrm{pH}$ 7.2). One unit (U) of protease activity was defined as the amount of enzyme required to raise the optical density at $440 \mathrm{~nm}$ by one unit after $1 \mathrm{~h}$

\subsection{Effect of inhibitors}

Protease inhibitors effect was investigated following the procedures of the manufacturer's guide of inhibitors. The inhibitors tested were: phenylmethylsulphonyl fluoride (PMSF) for serine proteases, ethylenediaminetetraacetic acid (EDTA) for metalloproteases, and iodoacetic acid (IAA) for cysteine proteases, at the concentration of $10 \mathrm{mM}$. For sensitivity determination, the enzyme was pre-incubated for $30 \mathrm{~min}$ at $37^{\circ} \mathrm{C}$ with the inhibitors. The residual activity was determined as the percentage of the proteolytic activity in an inhibitor-free control sample. After all, proceeded collagenolytic activity using the azocoll method.

\subsection{Polyacrylamide gel electrophoresis (SDS-PAGE)}

Samples were analyzed by SDS-PAGE in a $15 \%$ polyacrylamide gel, according to Laemmli [34]. The protein molecular markers were phosphorylase b $(97.0 \mathrm{kDa})$, bovine serum albumin $(66.0 \mathrm{kDa})$, ovalbumin $(54.0 \mathrm{kDa})$, carbonic anhydrase (30.0 kDa), trypsin inhibitor $(20.1 \mathrm{kDa})$ and $\alpha$ lactalbumin $(14.4 \mathrm{kDa})$. The gel was loaded with $20 \mu \mathrm{L}$ of concentrated enzyme by lyophilization, and subject to electrophoresis at a constant current of $100 \mathrm{~V}$. Gel was stained with $0.25 \%(\mathrm{w} / \mathrm{v})$ Comassie Brilliant Blue R-250 in methanol- 
acetic acid- water (45:10:45) and distained in the same solution without dye.

\subsection{Zymogram}

Proteolytic activity of enzyme bands was confirmed by zymogram analysis. To prepare a zymogram, concentrated enzyme was mixed under non-reducing conditions with SDS-PAGE sample buffer and electrophoresed in a $15 \%$ polyacrylamide with $0.1 \%(w / v)$ gelatin as substrate incorporated in the gel. Gel was loaded with $20 \mu \mathrm{L}$ of concentrated supernatant, subject to electrophoresis at a constant current of $100 \mathrm{~V}$ at $4{ }^{\circ} \mathrm{C}$ and incubated for $1 \mathrm{~h}$ at room temperature with $2.5 \%(\mathrm{v} / \mathrm{v})$ Triton $\mathrm{X}-100$ and for $18 \mathrm{~h}$ at $37{ }^{\circ} \mathrm{C}$ in $50 \mathrm{mM}$ Tris- $\mathrm{HCl}$ buffer, $\mathrm{pH} 9.0$. Gel was stained and distained as described in the previous section.

\section{RESULTS AND DISCUSSION}

\subsection{Enzyme production kinetics}

Table 2 reports data from earlier work related to the production of collagenolytic enzyme by different microorganisms. Among some fungi and bacteria, it can be seen that the Penicillium genus provides the highest values. Thus, this genus was selected for enzyme production. Moreover, there are few reports in the literature describing the production of collagenase by Penicillium. The values for collagenolytic activity reported on this work are about 2.7 times higher than existing data.

The composition of the culture medium is another aspect that must noticed. It is known that the costs of culture media and substrates are key factors on the production of industrial enzymes being thus necessary to develop processes that make use of inexpensive and easy to prepare substrates [8]. The use, as in the present work, of a low cost and readily available substrate, as is the case of gelatin and trace elements, may be an important step in the advancement of these processes. Figure 1 shows the results of enzyme kinetics production. At 96 hours it can be observed a sharp increase in the enzyme activity. Collagenolytic enzyme reached its maximum activity after 126 hours of fermentation $(379.80 \mathrm{U} / \mathrm{mL})$. Based on results, the incubation time used for further study was 126 hours. It can be observed a comparison between total protein in the culture broth and collagenolytic activity over fermentation time at Figure 1. The specific activity of collagenolytic enzyme was calculated as 1460.77 U/mg after 126 hours.

At Figure 1, after 126 hours it can be observed a gradual decrease in the biosynthesis of the enzyme, probably due to a period of microorganism adaptation to the medium containing only salts and gelatin or due to depletion of nutrients. The production effectiveness was evaluated by volumetric collagenolytic activity due to the industrial relevance of this parameter [8].

In addition, the enzyme concentration remained constant (a slight increase was observed) for the first 84 hours, most likely caused by the fungus need to get adapted to the poor culture medium, as compared to the other media listed in Table 4.

The maximum specific collagenolytic activity was obtained also at 126 hours of fermentation (1460.77 U/mg) (Figure 1). This value is much higher than other published results. Baehaki et al. [35] achieved a specific activity of $0.546 \mathrm{U} / \mathrm{mg}$, with Bacillus licheniformis; Jain and Jain [1] found $15.66 \mathrm{U} / \mathrm{mg}$ of specific activity by Streptomyces exfoliates, Wu et al. [6] obtained 2.77 U/mg using Bacillus pumilus, Mahmoud et al. [36], 97.12 U/mg with Aspergillus flavus and Ok and Hashinaga [37], 70.4 $\mathrm{U} / \mathrm{mg}$ with Zygosaccharomyces rouxii, all of them with more than 15 times lower activity than the produced by Penicillium sp. UCP 1286. The literature describes the importance of defining parameters that have a significant influence on the extracellular enzyme production by microorganisms - not only the composition of the culture medium as a carbon and nitrogen sources and trace elements should be considered but also the culture conditions such as $\mathrm{pH}$, temperature and stirring speed [23].

Table 2: Description of work reported in the literature relating to the production of collagenolytic enzymes.

\begin{tabular}{|c|c|c|c|c|}
\hline Microorganism & Culture Medium & Time (h) & $\mathbf{A}_{\mathbf{c}}(\mathrm{U} / \mathrm{mL})$ & References \\
\hline Aspergillus flavus & Collagen-dependent-medium & 144 & 82.95 & Mahmoud et al. (2007) \\
\hline Bacillus cereus & Glycerol and gelatin & 24 & 23.07 & Suphatharaprateep et al. (2011) \\
\hline Bacillus licheniformis & Yeast extract and collagen & N.I. & 3.10 & Baehaki et al. (2012) \\
\hline Bacillus licheniformis & Luria Broth and collagen & 35 & $0.546^{*}$ & Baehaki et al. (2014) \\
\hline Bacillus pumilus & Gelatin and Peptone & 24 & 35.97 & Wu et al. (2010) \\
\hline Bacillus subtilis & Yeast extract and gelatin & 14 & 3.07 & Tran and Nagano (2002) \\
\hline Candida albicans & Malt extract and gelatin & 72 & 5.00 & Lima et al. (2009) \\
\hline Klebsiella pneumoniae & Glycerol and gelatin & 24 & 10.53 & Suphatharaprateep et al. (2011) \\
\hline Penicillium aurantiogriseum & Soybean flour & 72 & 164.00 & Lima et al. (2011a) \\
\hline Penicillium aurantiogriseum & Soybean flour & 72 & 231.00 & Lima et al. (2011b) \\
\hline Rhizoctonia solani & Sabouraud, glucose and collagen & 108 & 212.33 & Hamdy (2008) \\
\hline Streptomyces exfoliatus & Soybean flour & 120 & 43.50 & Jain and Jain (2010) \\
\hline Zygosaccharomyces rouxii & Yeast extract, peptone and glucose & 50 & 70.4 & Ok and Hashinaga (1996) \\
\hline Penicillium sp. & Gelatin & 126 & 632.70 & Present work \\
\hline
\end{tabular}

$\mathrm{A}_{\mathrm{c}}=$ collagenolytic activity $(\mathrm{U} / \mathrm{mL}),{ }^{*}$ Specific activity $(\mathrm{U} / \mathrm{mg})$, N.I. = not informed. 


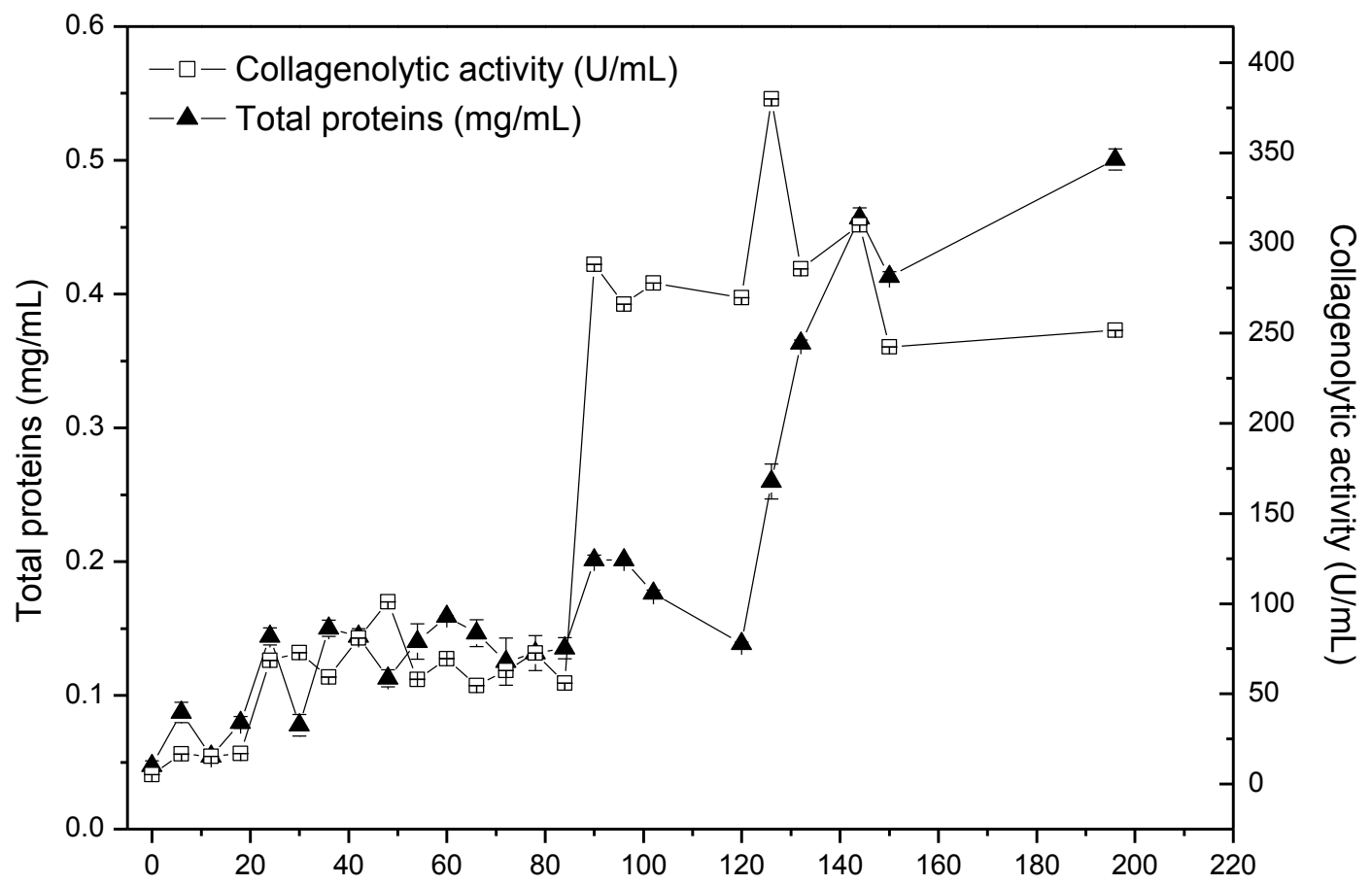

Fig 1: Collagenolytic activity and total protein content produced by Penicillium UCP 1286 isolated from Caatinga in gelatin culture medium.

Table 3: Conditions and results of fermentations conducted according to the $2^{4}$ factorial design.

\begin{tabular}{|c|c|c|c|c|c|c|c|c|}
\hline Run & pH & $\begin{array}{c}S_{\mathbf{o}}(\%) \\
\mathbf{w} / \mathbf{v})\end{array}$ & $\mathbf{T}\left({ }^{\circ} \mathbf{C}\right)$ & Agitation (rpm) & $\begin{array}{c}\mathbf{X} \\
(\mathrm{g} / \mathrm{L})\end{array}$ & $\mathbf{T P}(\mathrm{mg} / \mathrm{mL})$ & $\begin{array}{c}\mathbf{A}_{\mathbf{c}} \\
(\mathbf{U} / \mathbf{m L})\end{array}$ & $\begin{array}{c}\mathbf{a}_{\mathbf{c}} \\
(\mathbf{U} / \mathbf{m g})\end{array}$ \\
\hline 1 & 6 & 0.25 & 24 & 100 & 0.48 & 0.15 & 531.55 & 3603.73 \\
\hline 2 & 8 & 0.25 & 24 & 100 & 0.36 & 0.18 & 481.95 & 2744.20 \\
\hline 3 & 6 & 0.75 & 24 & 100 & 0.80 & 0.25 & 447.65 & 1786.13 \\
\hline 4 & 8 & 0.75 & 24 & 100 & 0.92 & 0.24 & 481.70 & 1996.68 \\
\hline 5 & 6 & 0.25 & 32 & 100 & 0.53 & 0.13 & 560.20 & 4351.07 \\
\hline 6 & 8 & 0.25 & 32 & 100 & 0.17 & 0.24 & 177.70 & 746.25 \\
\hline 7 & 6 & 0.75 & 32 & 100 & 0.62 & 0.26 & 396.65 & 1544.14 \\
\hline 8 & 8 & 0.75 & 32 & 100 & 0.72 & 0.19 & 349.50 & 1798.07 \\
\hline 9 & 6 & 0.25 & 24 & 200 & 0.45 & 0.16 & 632.70 & 3954.38 \\
\hline 10 & 8 & 0.25 & 24 & 200 & 0.30 & 0.16 & 471.20 & 2888.58 \\
\hline 11 & 6 & 0.75 & 24 & 200 & 0.98 & 0.36 & 475.10 & 1319.72 \\
\hline 12 & 8 & 0.75 & 24 & 200 & 0.40 & 0.36 & 424.15 & 1188.51 \\
\hline 13 & 6 & 0.25 & 32 & 200 & 0.48 & 0.12 & 468.05 & 3920.84 \\
\hline 14 & 8 & 0.25 & 32 & 200 & 0.51 & 0.15 & 424.10 & 2815.60 \\
\hline 15 & 6 & 0.75 & 32 & 200 & 0.53 & 0.32 & 405.95 & 1271.08 \\
\hline 16 & 8 & 0.75 & 32 & 200 & 0.38 & 0.20 & 338.65 & 1662.09 \\
\hline 17 & 7 & 0.5 & 28 & 150 & 0.77 & 0.22 & 427.95 & 1923.37 \\
\hline 18 & 7 & 0.5 & 28 & 150 & 0.75 & 0.23 & 424.85 & 1882.99 \\
\hline 19 & 7 & 0.5 & 28 & 150 & 0.72 & 0.24 & 432.90 & 1842.13 \\
\hline 20 & 7 & 0.5 & 28 & 150 & 0.74 & 0.23 & 428.80 & 1874.54 \\
\hline
\end{tabular}

Results related to 126 hours of fermentation. $\mathrm{pH}=$ initial $\mathrm{pH}$ of the medium; $\mathrm{S}_{\mathrm{o}}=$ initial concentration of gelatin; $\mathrm{T}=$ temperature; $\mathrm{X}=$ biomass concentration; TP $=$ total protein; $A_{c}=$ volumetric collagenolytic activity; $a_{c}=$ specific collagenolytic activity.

\section{2. $2^{4}$ Factorial Design}

Table 3 shows fermentations conditions and results after 126 hours of production. The highest values of collagenolytic activity $(632.70 \mathrm{U} / \mathrm{mL})$ and specific activity $(3954.38 \mathrm{U} / \mathrm{mg})$ were obtained in run 9 , conducted using $0.25 \%(\mathrm{w} / \mathrm{v})$ gelatin, $200 \mathrm{rpm}$, pH 6.0 and $24^{\circ} \mathrm{C}$.

The factorial design increased the enzyme production by about $65 \%$ compared to the preliminary results achieved on the kinetics experiments, obtaining a collagenolytic activity of 632.70 $\mathrm{U} / \mathrm{mL}$. According to Jain and Jain [1], the maximum production obtained for Streptomyces exfoliates $(43.5 \mathrm{U} / \mathrm{mL})$ was observed after 5 days of culture at $30{ }^{\circ} \mathrm{C}$ and $150 \mathrm{rpm}$. Lima et al. [23] conducted a $2^{3}$ full factorial for the production of collagenase with Candida albicans and found the highest value $(7.6 \mathrm{U} / \mathrm{mL})$ with a $2 \%$ substrate concentration, agitation of $160 \mathrm{rpm}$ and $\mathrm{pH} 7.0$. For Penicillium aurantiogriseum, Lima et al. [9] reported that the 
highest values of collagenolytic activity $(164 \mathrm{U} / \mathrm{mL})$ and biomass concentration $(1.8 \mathrm{~g} / \mathrm{L})$ were obtained with $0.75 \%$ substrate concentration, $200 \mathrm{rpm}, \mathrm{pH} 8.0$ and $28^{\circ} \mathrm{C}$. The results described in this paper show that the concentration of substrate $(0.25 \%)$ used for the maximum production of collagenolytic enzyme (632.70 $\mathrm{U} / \mathrm{mL}$ ) was lower than those reported in the literature, which can represent an economy in production. With respect to the agitation, the results were similar to those related by Lima et al. [9] (200 $\mathrm{rpm})$. Temperature found in present work was lower than others papers $\left(24{ }^{\circ} \mathrm{C}\right)$, and $\mathrm{pH}$ was slightly higher (9.0) showing that maximum enzyme production conditions are milder than those reported.

A full factorial model was designed to compare the activity data. This model included four main effects, six twofactor, four three-factor and one four-factor interactions. The statistically significant estimates of the effects (at the 95\% confidence level) are listed of Table 4 . The values of the significant effects indicate that, on average, higher values of collagenolytic activities were obtained when factors $1(\mathrm{pH})$ and 3 (temperature) were selected at their lowest levels, both with negative effects. With respect to the effect of the factors on the biomass concentration, the gelatin concentration was the only one that presented positive significant effect.

Table 4: Statistically significant main effects and interactions estimated from the collagenolytic activity and biomass concentration values listed in Table 2

\begin{tabular}{lcc}
\hline \multicolumn{1}{c}{ Factors } & $\begin{array}{c}\text { Effects on } \\
\text { collagenolytic activity }\end{array}$ & $\begin{array}{c}\text { Effects on } \\
\text { biomass } \\
\text { concentration }\end{array}$ \\
\hline (1) $\mathrm{pH}$ & $-96.11^{*}$ & -0.14 \\
(2) Gelatin concentration & -53.51 & $0.25^{*}$ \\
(3) Temperature & $-103.15^{*}$ & -0.09 \\
(4) Agitation & 26.62 & -0.07 \\
1 by 2 & 63.27 & 0.01 \\
1 by 3 & -39.11 & 0.04 \\
1 by 4 & 15.19 & -0.07 \\
2 by 3 & 18.70 & -0.12 \\
2 by 4 & -34.54 & -0.12 \\
3 by 4 & 11.55 & 0.04 \\
\hline *Significa
\end{tabular}

*Significant

Temperature is an important factor in regulating enzymatic synthesis [38]. In a study reporting the production of collagenase by Penicillium aurantiogriseum, the temperature also had a negative effect [9]. Since the initial $\mathrm{pH}$ of the culture medium influences many enzymatic processes, enzyme production, cell transport across membranes and expression of extracellular proteases, we observed, a gradual decrease in collagenase production when the external $\mathrm{pH}$ was raised from 6 to 8. Suphatharaprateep et al. [2] reported that the optimal initial $\mathrm{pH}$ for collagenase production from Klebsiella pneumonia and Bacillus cereus were 7.5 and 6.0, respectively.

Regarding the effect of the different factors on biomass concentration, only the concentration of gelatin (2) proved to be statistically significant. Jain and Jain [1] showed that the maximum collagenase production $(43.50 \mathrm{U} / \mathrm{mL})$ was observed with higher biomass concentration $\left(5.60 \mathrm{~cm}^{3}\right.$ of cells). The initial $\mathrm{pH}$ of the medium was shown by Lima et al. [9] to be the factor that exhibited a significantly higher effect on the biomass, with an increase in $\mathrm{pH}$ causing a decrease in cell growth.

With a $2^{4}$ experimental design, it was possible to establish fermenting conditions that allowed for a $66 \%$ increase in the enzyme activity as compared to the initially obtained values. It is observed that maximum collagenolytic production occurred when lowest concentration of substrate and temperature were utilized, which facilitates industrial process, reducing costs.

\subsection{Effect of pH on collagenolytic activity and stability}

Figure 2(A) shows the $\mathrm{pH}$ dependence of collagenolytic activity in azocoll. The enzyme was found to be very active between $\mathrm{pH} 7.0$ and 9.0. At $\mathrm{pH} 6.0$, only $20 \%$ of the activity remained, and the results were even worse for the most acidic conditions ( $\mathrm{pH} 3.0$ to 5.0) and more basic (pH 10 and 11). Figure 2(B) shows the stability at $\mathrm{pH}$ between 3.0 and 11.0, during 24 hours of incubation at $4{ }^{\circ} \mathrm{C}$, the selected storage temperature. The enzyme was quite stable between $\mathrm{pH} 7.0$ and 9.0, keeping about 85 to $90 \%$ of stability, after 24 hours. With the $\mathrm{pH} 5.0$ and 6.0 , the residual activity decreased to $70 \%$. In others values of $\mathrm{pH}$, the activity was below $30 \%$.

Concerning $\mathrm{pH}$ effect on collagenolytic activity, Jain and Jain [1] determined the collagenase activity from Streptomyces exfoliatus at different $\mathrm{pH}$ (4-10) and found that the enzyme retained $65 \%$ residual activity at $\mathrm{pH} 10$ as compared to its optimum activity at $\mathrm{pH}$ 7. The collagenase from Klebsiella pneumoniae had an optimum $\mathrm{pH}$ range from 6.0 to 8.0 , with maximal activity at 7.0 in Tris- $\mathrm{HCl}$ buffer while Bacillus cereus collagenase activity was recorded as the highest in the $\mathrm{pH}$ range of 5.4-8.2 [2]. The collagenase from Bacillus pumilus [6] was evaluated in a range from 3 to 10 being the highest activity at $\mathrm{pH}$ 7.5. Baehaki et al. [35] used a pH range between 2 and 12 and observed the maximum activity at $\mathrm{pH}$ 9.0. Lima et al. [9] showed that the enzyme produced by $P$. aurantiogriseum was very active at the $\mathrm{pH}$ range 8 to 10 , and the highest activity occurred at $\mathrm{pH}$ 9.0, as in the present work. Ok and Hashinaga [37] related that optimum $\mathrm{pH}$ to collagenase produced by Zygosaccharomyces rouxii was 8.2 . Only the enzyme produced by Rhizoctonia solani was produced under acid pH (5.0) [14]. The results described at present work are in agreement with those reported in literature that show that collagenases exhibit optimum activity values under neutral or alkaline conditions [23,39]. These results indicate that this collagenolytic enzyme belongs to the group of alkaline proteases.

Lima et al. [9] evaluated collagenase stability at $\mathrm{pH}$ range 3.0 to 11.0 . The enzyme was stable between $\mathrm{pH} 6.0$ and 10.0 during the first $8 \mathrm{~h}$, but after $28 \mathrm{~h}$ its stability was restricted to a $\mathrm{pH}$ range from $7.0(50.7 \%)$ to $9.0(75.1 \%)$. In accordance with $\mathrm{Wu}$ et al. [6], collagenase from B. pumilus is stable between $\mathrm{pH} 6.5$ and 8 , the enzyme retained above $84 \%$ of full activity after $30 \mathrm{~min}$. By retaining more than $80 \%$ of its stability at $\mathrm{pH} 8$ and 9 , the enzyme described in the present work proved to be very stable in comparison with the collagenase produced by other microorganisms. 

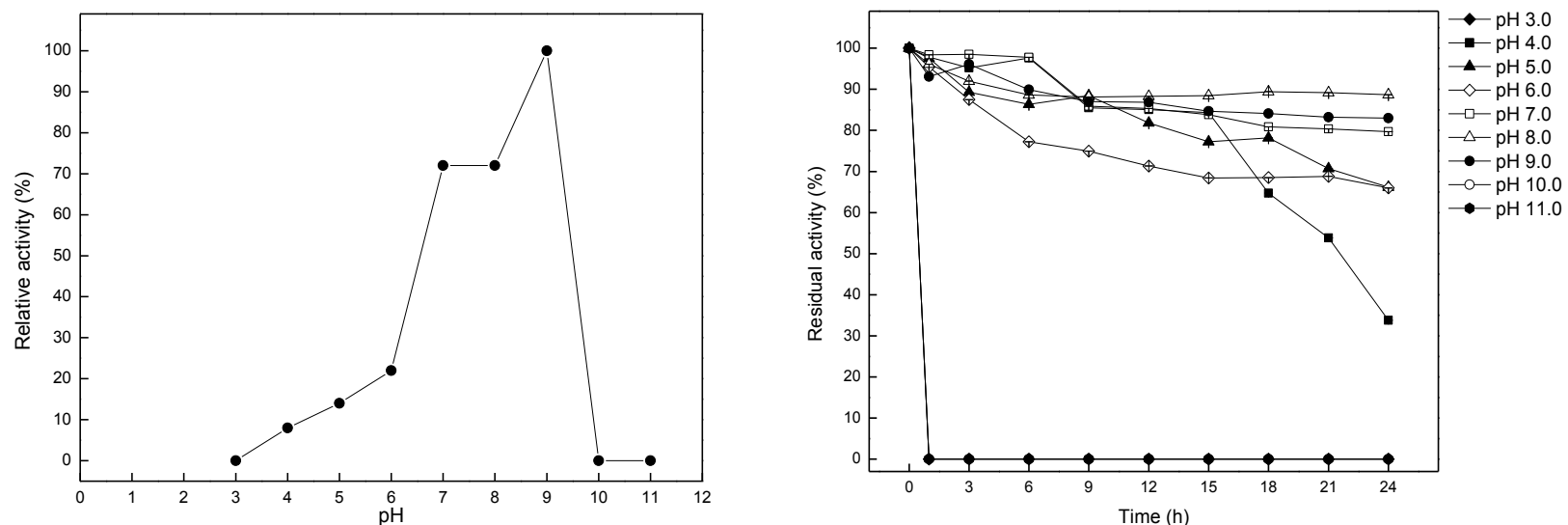

Fig. 2: (A) Effect of $\mathrm{pH}$ on the activity of extracellular collagenase produced by Penicillium sp. UCP 1286 isolated from Caatinga, expressed as percentage of the maximum one obtained in $0.05 \mathrm{M}$ Tris- $\mathrm{HCl}$ buffer ( $\mathrm{pH}$ 9.0). (B) Effect of $\mathrm{pH}$ on the stability of extracellular collagenase produced by Penicillium sp. UCP 1286 isolated from Caatinga, expressed as the residual activity with respect to that at the beginning. Each value is the average of results of three experiments, and the error bars show the standard deviations.
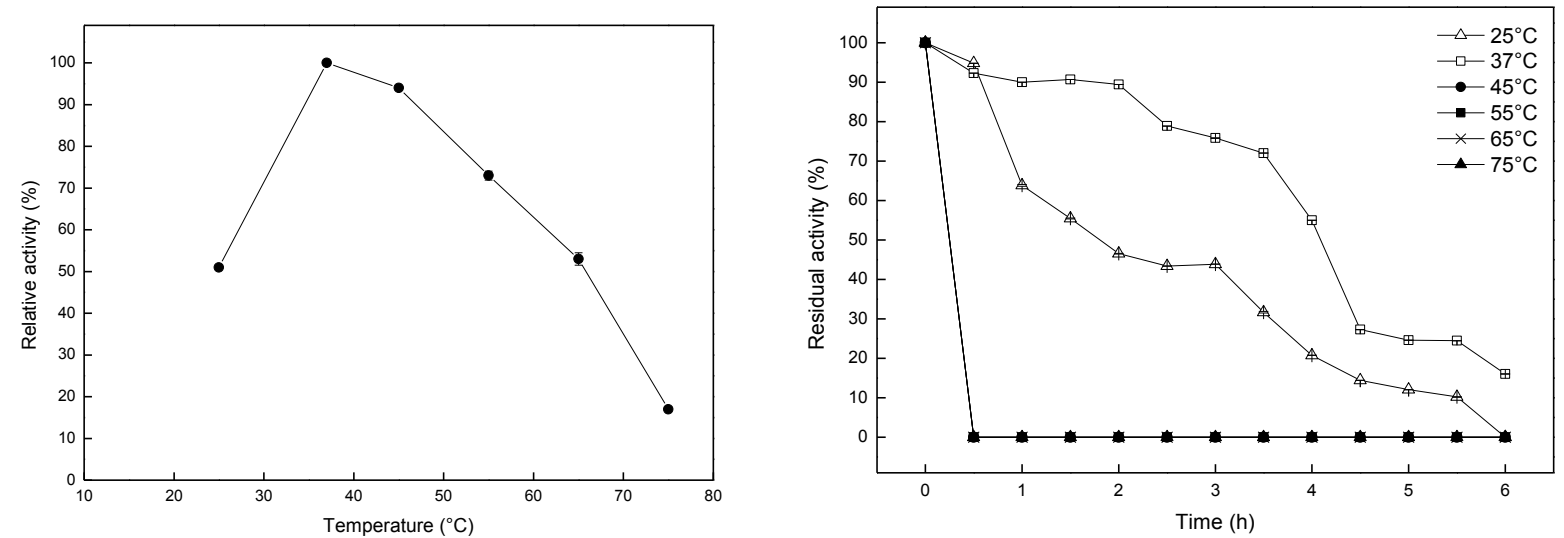

Fig. 3: (A) Effect of temperature on the activity of extracellular collagenase produced by Penicillium sp. UCP 1286 isolated from Caatinga, expressed as percentage of the maximum one obtained at $37^{\circ} \mathrm{C}$. (B) Effect of temperature on the stability of extracellular collagenase produced by Penicillium sp. UCP 1286 isolated from Caatinga, expressed as the residual activity with respect to that at the beginning. Each value is the average of the results of three experiments, and the error bars show the standard deviations.

\subsection{Effect of temperature on collagenolytic activity \& stability}

Figure 3(A) shows that the highest value is observed at $37{ }^{\circ} \mathrm{C}$. At $45^{\circ} \mathrm{C}$, approximately $85 \%$ of the enzymatic activity still remained, and then a gradual decrease occurs until almost all activity is lost at $75{ }^{\circ} \mathrm{C}$. Figure 3(B) shows the results of enzyme stability over 6 hours at the different temperatures evaluated. A gradual decrease on enzyme stability was observed for 25 and 37 ${ }^{\circ} \mathrm{C}$, while for the other temperatures considered, after the first 30 minutes, no collagenolytic activity was observed.

Comparing results of temperature assays, Wu et al. [6] found for B. pumilus collagenase an optimum temperature of 45 ${ }^{\circ} \mathrm{C}$, and with heating, the collagenase retained above $50 \%$ activity at $70{ }^{\circ} \mathrm{C}$. Baehaki et al. [35] assayed the collagenase activity between 30 and $90{ }^{\circ} \mathrm{C}$, being observed an increase in enzymatic activity between 30 and $50{ }^{\circ} \mathrm{C}$, with a strong reduction occurring above $60{ }^{\circ} \mathrm{C}$. S. exfoliatus showed the maximum collagenase activity at $70{ }^{\circ} \mathrm{C}$ [1]. In the study of Suphatharaprateep et al. [2], both $K$. pneumoniae and $B$. cereus were shown to produce collagenases with the optimal temperature of $37{ }^{\circ} \mathrm{C}$. Hamdy [14] related optimal temperature for $R$. solani collagenase at $40{ }^{\circ} \mathrm{C}$.
For $P$. aurantiogriseum collagenase, the optimal temperature was also $37{ }^{\circ} \mathrm{C}$; at temperature lower or higher than $37{ }^{\circ} \mathrm{C}$, the collagenase production decreased, as well as in the present work [9].

Figure 3B shows collagenase stability to temperature. At 25 and $37{ }^{\circ} \mathrm{C}$, the enzyme retained about $90 \%$ and $60 \%$ of its enzymatic activity after 1.5 hours of incubation. After this period, the values were gradually decreased until reaching $15 \%$ at $37{ }^{\circ} \mathrm{C}$ after 6 hours and about $10 \%$, at $25{ }^{\circ} \mathrm{C}$ after 5.5 hours. Regarding the others temperatures, may have occurred protein denaturation. The enzyme from $P$. aurantiogriseum was stable after $1.5 \mathrm{~h}$ incubation in the temperature range 25 to $45{ }^{\circ} \mathrm{C}$, retaining 96.2, 96.3 , and $81.6 \%$ of its initial activity at 25,37 , and $45{ }^{\circ} \mathrm{C}$, respectively while at $70{ }^{\circ} \mathrm{C}$ its activity was completely lost after only $15 \mathrm{~min}$ [9].

The results for a collagenase from $B$. licheniformis showed that the enzyme remained relatively stable and retained above $50 \%$ activity under $20 \mathrm{~min}$ incubation at 50 and $70{ }^{\circ} \mathrm{C}$. However, the enzyme activity decreased gradually after $20 \mathrm{~min}$ incubation [35]. 


\subsection{Substrate specificity}

Five protein substrates were tested (azocoll, type I collagen, type $\mathrm{V}$ collagen, gelatin and azocasein). Besides azocasein, the culture filtrate showed activity on all of the substrates. Higher enzyme activity was observed with azocoll as substrate $(692.65 \mathrm{U} / \mathrm{mL}$ and $3463.25 \mathrm{U} / \mathrm{mg})$. The enzyme's activity towards azocoll was assumed as $100 \%$ (Figure 4). The relative activity on other substrates was lower, but it can be observed that the enzyme produced by Penicillium sp. UCP 1286 has much higher affinity for collagen-derived substrates when compared to noncollagen-derived substrate azocasein.

Commercial enzyme produced by Clostridium hystolyticum exhibits highest affinity for collagen type I (32.22\% relative activity) when compared to the collagenolytic enzyme produced in this work, that presented higher relative values for type V collagen $(46.90 \%)$ and gelatin $(22.41 \%)$ (Figure 4$)$.

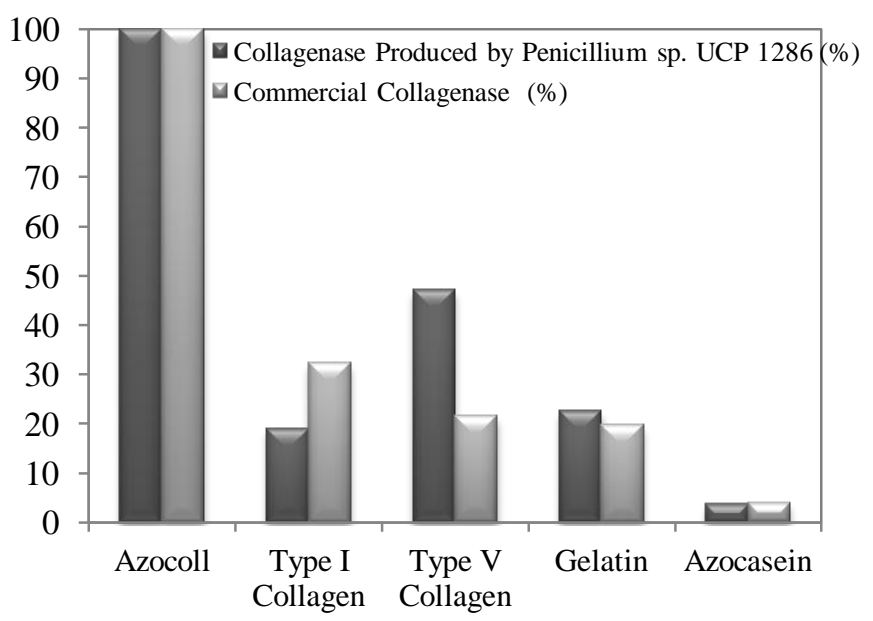

Fig. 4: Substrate specificity of Collagenase from Penicillium sp. UCP 1286 and Commercial Collagenase (produced by Clostridium hystolyticum). The enzyme's activity towards azocoll was assumed as $100 \%$.

The action of collagenase is very specific, acting only on collagen and gelatin and not on any of the other usual protein substrates [15]. Lima et al. [9] showed that $P$. aurantiogriseum collagenase highest activity was also obtained with azocoll (164.00 U/mL and $393.00 \mathrm{U} / \mathrm{mg}$ ). Hamdy [14] related specificity of collagenase produced by $R$. solani to gelatin and collagen (33.23 U/mg and $120 \mathrm{U} / \mathrm{mg}$, respectively). Ok and Hashinaga [37] tested collagenase activity using soluble $(27.1 \mathrm{U} / \mathrm{mL})$ and insoluble collagen $(5.6 \mathrm{U} / \mathrm{mL})$, besides synthetic peptides as $\mathrm{Cbz}$ GPLGP $(21.1 \mathrm{U} / \mathrm{mL})$ and FALGPA $(0.41 \mathrm{U} / \mathrm{mL})$. The collagenase produced by $B$. licheniformis exhibited the highest activity on casein, being also able to hydrolyze collagen, gelatin and fibrin [35]. For B. pumilus collagenase, in addition to hydrolyzing the native collagen from bovine Achilles tendon, it was also able to act on gelatin, with a cleavage rate of $50.72 \%$ and $62.56 \%$, respectively [6]. Among the collagen types, type $\mathrm{V}$ is classified as a member of the family of fibrillar collagens, based on their primary structure and their potential to form fibrils in the interstice $[40,41]$. This type of collagen has been described as involved in maintenance processes of vascular injury in patients with certain diseases, such as systemic lupus erythematosus and vasculitis [42]. More specific studies are required to better understand the action of the enzyme produced by Penicillium sp. UCP 1286 against type $\mathrm{V}$ collagen, but already indicates a potential biotechnological application for this protease (Figure 4).

\subsection{Effects of inhibitors}

The culture filtrates obtained from Penicillium sp. UCP 1286 was subjected to inhibition by phenylmethylsulfonyl fluoride (PMSF), which is a method to establish whether or not one enzyme is a serine protease. After incubation with PMSF, the enzyme activity was reduced to 0 , whereas in the presence of iodoacetic acid (that inhibits cysteine proteases) there was maintenance of a residual activity of $88.31 \%$. The collagenolytic enzyme was slightly inhibited by EDTA, known to inhibit metalloproteinases (a loss of only about 6\% of activity was observed). Enzyme inhibitors are molecules that interact with the enzyme or compounds that chelate metal ions required by the enzyme to maintain its conformation [16]. In particular, the conditions selected for tests with PMSF were consistent with the observations of James [43], and those for tests with EDTA according Hamdy [14]. Although more tests for a complete characterization of the enzyme are required, the preliminary results suggest that the enzyme belongs to the family of collagenolytic serine proteases, since it was completely inhibited by their reversible inhibitor of serine proteases. The collagenolytic enzyme from $P$. aurantiogriseum kept only $24 \%$ on its activity in presence of PMSF, and retained 100 and $93.6 \%$ of its activity in the presence of iodoacetic acid and EDTA [9]. The enzyme produced by Bacillus pumilus was strongly inhibited by EDTA [6]. As in the present work, Jain and Jain [1] showed that the collagenase produced by $S$. exfoliates completely lost its activity in the presence of PMSF and retained $65.91 \%$ in the presence of EDTA. Mahmoud et al. [36] tested inhibition of collagenase produced by A. flavus using cetrimide, a reversible competitive inhibitor against collagenase, and collagenolytic activity was 0 with $1 \mathrm{mg} / \mathrm{mL}$ of cetrimide. The results of Hamdy [14] showed that collagenase by $R$. solani was inhibited by EDTA ( $31 \%$ of relative activity), iodoacetate (18\%) and sodium arsenite (13\%).

\subsection{Electrophoresis and Zymogram}

Electrophoresis was used for collagenolytic enzyme characterization, estimating its molecular weight. Reported molecular weights vary significantly based on the enzyme type (serine or metallocollagenase) and the source (microbial or animal tissue) [16]. Electrophoresis and zymogram of the culture filtrate and $60-80 \%$ fraction from saline precipitation are presented in Figure $5 \mathrm{~A}$ and $5 \mathrm{~B}$, respectively. The electrophoresis presented a major band corresponding to a molecular mass (MM) of approximately $37 \mathrm{kDa}$, while others proteins can be observed at 28 and $29 \mathrm{kDa}$ (Figure 5A). The zymogram analysis (Figure 5B) confirmed the bands collagenolytic activity. It can be observed that 
the $60-80 \%$ fraction showed 4 bands at the lowest protein volume concentration applied $(10 \mu \mathrm{g})$, with approximately $140 \mathrm{kDa}, 120$ $\mathrm{kDa}, 100 \mathrm{kDa}$ and $37 \mathrm{kDa}$ with activity towards gelatin. Multiple collagenases have been reported at literature by zymography [35,44]. Roy et al. [45] reported that serine collagenases have, typically, molecular weights in the range of 24 and $36 \mathrm{kDa}$. Baehaki et al. [35] found several protein bands and zymography analysis indicated that the molecular mass of collagenase fractions were approximately 124, 35, 31 and $26 \mathrm{kDa}$ from B. licheniformis. Baehaki et al. [44] reported multiple collagenases in range 14.5 $210 \mathrm{kDa}$ produced by $B$. licheniformis. Sakurai et al. [39] produced a purified collagenase from $S$. parvulus with a relative molecular mass of $52 \mathrm{kDa}$. Matsushita et al. [46] reported that collagenases isolated from related species of $C$. perfringens had molecular weights ranging from 80 to $120 \mathrm{kDa}$. Mahmoud et al. [36] related a collagenase produced from A. flavus with molecular weights between 72 and $92 \mathrm{kDa}$. Hamdy [14] produced a purified collagenase from $R$. solani that showed a molecular weight at 66 $\mathrm{kDa}$. Some researchers isolated serine collagenases from digestive glands of marine organism with molecular weights $<60 \mathrm{kDa}$ $[47,48]$. The wide range of molecular weight is to be expected for an enzyme such as collagenase that does not have a single structure [16].

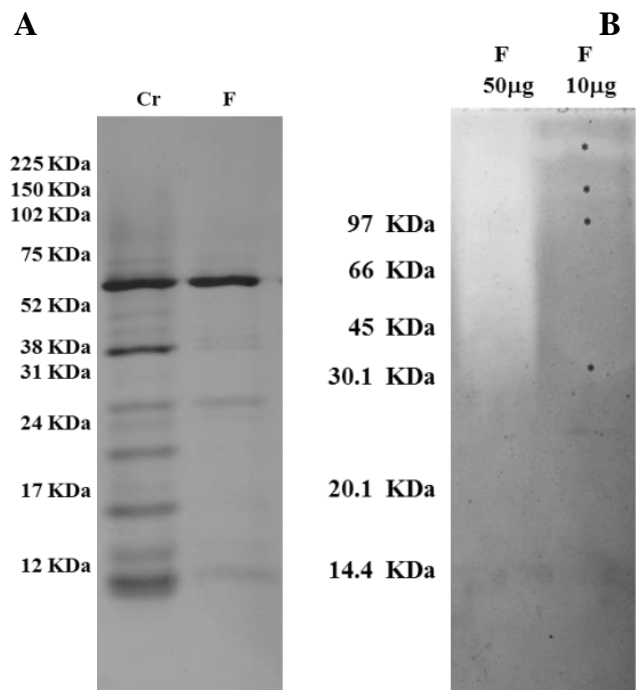

Fig. 5: (A) SDS-PAGE patterns of Penicillium UCP 1286 crude extract (Cr) and $60-80 \%$ fraction obtained from precipitation with ammonium sulfate $(\mathrm{F})$. MM: molecular mass. (B) Zymogram analysis of collagenase.

\section{CONCLUSIONS}

The Penicillium sp. UCP 1286 fungus isolated from Caatinga was shown to produce large amounts of extracellular collagenase, using only gelatin as carbon and nitrogen source. Moreover, the activity of produced collagenolytic enzyme was much higher that other microbial production systems reported in the literature. This makes this production system as a very promising alternative for collagenase production as it associates a high producer microbial with the use of an inexpensive and readily available substrate. Complementary, optimal enzyme production conditions were established, with the temperature showing the greatest effect. The enzymes was seems to be a serine alkaline protease, having the optimal collagenolytic activity at $37^{\circ} \mathrm{C}$ and pH 9.0. Concerning specificity, the produced enzyme hydrolyses different types of collagen, including azocoll, type I, type $\mathrm{V}$ and gelatin. The data indicates that the produced enzyme presents a higher affinity to type $\mathrm{V}$ collagen and gelatin, when compared to commercial colagenase. Also, low azocasein activity indicates a collagen specificity of this produced enzyme, desirable property for many applications.

\section{ACKNOWLEDGMENTS}

This work was supported by Fundação de Amparo à Ciência e Tecnologia do Estado de Pernambuco (FACEPE) (IBPG-0137-2.08/12) and Conselho Nacional de Desenvolvimento Científico e Tecnológico (CNPq). Sara Silvério also acknowledges her post-doc grant (SFRH/BPD/88584/2012) from FCT (Fundação para a Ciência e a Tecnologia), Portugal.

\section{REFERENCES}

1. Jain R, Jain PC. Production and partial characterization of collagenase of Streptomyces exfoliatus CFS 1068 using poultry feather. Indian J Exp Biol 2010;48:174-8.

2. Suphatharaprateep W, Cheirsilp B, Jongjareonrak A. Production and properties of two collagenases from bacteria and their application for collagen extraction. N Biotechnol 2011;28:649-55.

3. Di Lullo G a., Sweeney SM, Körkkö J, Ala-Kokko L, San Antonio JD. Mapping the ligand-binding sites and disease-associated mutations on the most abundant protein in the human, type I collagen. J Biol Chem 2002;277:4223-31.

4. Müller WEG. The origin of metazoan complexity: porifera as integrated animals. Integr Comp Biol 2003;43:3-10.

5. Tran LH, Nagano H. Isolation and Characteristics of Bacillus subtilis CN2 and its Collagenase Production. Food Microbiol Saf 2002;67:36.

6. Wu Q, Li C, Li C, Chen H, Shuliang L. Purification and characterization of a novel collagenase from Bacillus pumilus Col-J. Appl Biochem Biotechnol 2010;160:129-39.

7. Dresden $\mathrm{MH}$. Evidence for the role of collagenase in collagen metabolism. Nature 1971.

8. Lima CA, Viana Marques DA, Neto BB, Lima Filho JL, Carneiro-daCunha MG, Porto ALF. Fermentation medium for collagenase production by Penicillium aurantiogriseum URM4622. Biotechnol Prog 2011;27:1470-7.

9. Lima CA, Filho JLL, Neto BB, Converti A, Carneiro da Cunha MG, Porto ALF. Production and characterization of a collagenolytic serine proteinase by Penicillium aurantiogriseum URM 4622: A factorial study. Biotechnol Bioprocess Eng 2011;16:549-60.

10. Lima CA, Júnior ACVF, Filho JLL, Converti A, Marques D a. V, Carneiro-da-Cunha MG, et al. Two-phase partitioning and partial characterization of a collagenase from Penicillium aurantiogriseum URM4622: Application to collagen hydrolysis. Biochem Eng J 2013;75:64-71.

11. Ravanti L, Kahari VM. Matrix metalloproteases in wound repair. Int J Mol Med 2000;6:391-407.

12. Shanmughapriya S, Kiran GS, Natarajaseenivasan K. Optimization of extracellular thermotolerant alkaline protease produced by marine Roseobacter sp. (MMD040). Bioproc Biosys Eng 2008;31:427-33.

13. Barret AJ, Rawlings ND, Woessner JF. Handbook of Proteolytic Enzymes. 2nd. ed. Oxford, U. K.: 2004.

14. Hamdy HS. Extracellular collagenase from Rhizoctonia solani: Production, purification and characterization. Indian $\mathrm{J}$ Biotechnol 2008;7:333-40. 
15. Rao MB, Tanksale a M, Ghatge MS, Deshpande V V. Molecular and biotechnological aspects of microbial proteases. Microbiol Mol Biol Rev 1998;62:597-635.

16. Daboor SM, Budge SM, Ghaly AE, Brooks S, Dave D. Extraction and Purification of Collagenase Enzymes: A Critical Review. Am J Biochem Biotechnol 2010;6:239-63.

17. Mookthiar K, Steinbrink SD, Van Wart HE. Mode of hydrolysis of collagen-like peptidase by class I and class II Clostridium hystolyticum collagenases: Evidence for both endopeptidase and tripeptidylcarboxypeptidase activities. Biochemistry1 985;24:6527-33.

18. Peterkofsky B. Bacterial collagenase. Methods Enzym 1982;82:45371.

19. Sandhya C, Sumantha A, Szakacs G, Pandey A. Comparative evaluation of neural protease production by Aspergillus oryzae in submerged and solid state fermentation. Process Biochem 2005;40:2689-94.

20. Yakovleva MB, Khoang TL, Nikitina ZK. Collagenolytic activity in several species of deuteromycetes under various storage conditions. Appl Biochem Microbiol 2006;42:431-4.

21. de Siqueira ACR, da Rosa NG, Motta CMS, Cabral H. Peptidase with keratinolytic activity secreted by Aspergillus terreus during solid-state fermentation. Brazilian Arch Biol Technol 2014;57:514-22.

22. Rosso BU, Lima CDA, Porto TS, de Oliveira Nascimento C, Pessoa $\mathrm{A}$, Converti A, et al. Partitioning and extraction of collagenase from Penicillium aurantiogriseum in poly(ethylene glycol)/phosphate aqueous two-phase system. Fluid Phase Equilib 2012;335:20-5.

23. Lima CA, Rodrigues PMB, Porto TS, Viana D a., Lima Filho JL, Porto ALF, et al. Production of a collagenase from Candida albicans URM3622. Biochem Eng J 2009;43:315-20.

24. Viani FC, Cazares Viani PR, Gutierrez Rivera IN, da Silva ÉG, Paula CR, Gambale W. Actividad proteolítica extracelular y análisis molecular de cepas de Microsporum canis aisladas de gatos con y sin sintomatología. Rev Iberoam Micol 2007;24:19-23.

25. Ikram-Ul-Haq H, Mukhtar. Biosynthesis of acid proteases by Penicillium griseoroseum $\mathrm{IH}-02$ in solid-state fermentation. Pakist $\mathrm{J}$ Bot 2007;39:2717-24.

26. Menezes R, Sampaio E, Giongo V, Pérez-Marin A. Biogeochemical cycling in terrestrial ecosystems of the Caatinga Biome. Brazilian $\mathrm{J}$ Biol 2012;72:643-53.

27. Ferreira ACC, Leite LFC, de Araújo ASF, Eisenhauer N. Land-Use Type Effects on Soil Organic Carbon and Microbial Properties in a Semi-Arid Region of Northeast Brazil. L Degrad Dev 2014;178:n/a n/a.

28. Pacchioni RG, Carvalho FM, Thompson CE, Faustino ALF, Nicolini F, Pereira TS, et al. Taxonomic and functional profiles of soil samples from Atlantic forest and Caatinga biomes in northeastern Brazil. Microbiologyopen 2014;3:299-315.

29. Chavira RJ, Burnett TJ, Hageman JH. Assaying Proteinases with Azocoll. Anal Biochem 1984;136:446-50.

30. Bradford MM. A rapid and sensitive method for the quantitation of microgram quantities of protein utilizing the principle of protein-dye binding. Anal Biochem 1976;72:248-54

31. Endo A, Murakawa S, Shimizu H, Shiraishi Y. Purification and properties of collagenase from Streptomyces species. J Biochem 1987;102:163-70.

32. Rosen H. A modified ninhydrin colorimetric analysis for amino acids. Arch Biochem Biophys 1975;67:10-5.

33. Moore S, Stein WH. Photometric ninhydrin method for use in the chromatography of amino acids. J Biol Chem 1948;176:367-88.

34. Laemmli UK. Cleavage of structural proteins during the assembly of the head of bacteriophage T4. Nature 1970;227:680-5.

35. Baehaki A, Sukamo, Syah D, Setyahadi S, Suhartono MT. Production and characterization of collagenolytic protease from Bacillus licheniformis F11.4 originated from Indonesia. Asian J Chem 2014;26:2861-4.
36. Mahmoud Y a.-G, Abu El-Souod SM, El-Shourbagy SM, El-Badry ASM. Characterisation and inhibition effect of cetrimide on collagenase produced by Aspergillus flavus, isolated from mycotic ulcers. Ann Microbiol 2007;57:109-13.

37. Ok T, Hashinaga F. Detection and production of extracellular collagenolytic enzyme from Zygosaccharomyces rouxii. J Gen Appl Microbiol 1996;42:517-23.

38. Chellapan S, Jasmin C, Basheer SM, Elyas K, Bhat SG, Chandrasekaran M. Production, purification and partial characterization of a novel protease from marine Engyodontium album BTMFS10 under solid station fermentation. Process Biochem 2006;41:956-61.

39. Sakurai Y, Inoue $\mathrm{H}$, Nishii $\mathrm{W}$, Takahashi T, Iino $\mathrm{Y}$, Yamamoto $\mathrm{M}$, et al. Purification and characterization of a major collagenase from Streptomyces parvulus. Biosci Biotechnol Biochem 2009;73:21-8.

40. Adachi E, Hayashi T. "In vitro" formation of fine fibrils with a Dperiodic banding pattern type V collagen. Relat Res 1985;5:225-32.

41. Kiriviko KI, Mlyllyla R. Biosynthesis of the collagens. In: Piez KA, Reddi AH, organizadores. Extracell. Matrix Biochem., New York: Elsevier; 1984, p. 83-118.

42. Moreland LW, Gay RE, Gay S. Collagen autoantibodies in patients with vasculitis and systemic lupus erythematosus. Clin Immunol Immunopathol 1991;60:412-218.

43. James GT. Inactivation of the protease inhibitor phenylmethylsulfonyl fluoride in buffers. Anal Biochem 1978;86:574-9.

44. Baehaki A, Suhartono MT, Syah D, Sitanggang AB, Setyahadi S, Meinhardt F. Purification and characterization of collagenase from Bacillus licheniformis F11.4. African J Microbiol Res 2012;6:2373-9.

45. Roy P, Colas B, Durand P. Purification, kinetical and molecular characterizations of a serine collagenolytic protease from greenshore crab (Carcinus maenas) digestive gland. Comp Biochem Physiol 1994;36:247-301.

46. Matsushita K, Toyama H, Adachi O. Respiratory chains and bioenergetics of acetic acid bacteria. Adv Microb Physiol 1994;36:247-301.

47. Kristjánsson MM, Gudmundsdóttir S, Fox JW, Bjamason JB. Characterization of collagenolytic serine proreinase from the Atlantic cod (Gadus morhua). Comp Biochem Physiol 1995;110:707-17.

48. Sivakumar P, Sampath P, Chandrakasan G. Collagenolytic metalloprotease (gelatinase) from the hepatopancreas of the marine crab, Scylla serrata. Comp Biochem Physiol 1999;123:273-9.

\section{How to cite this article:}

Wanderley MCA, Neto JMWD, Lima CA, Silverio SIC, Filho JLL, Teixeira JAC, Porto ALF. Production and Characterization of Collagenase by Penicillium sp. UCP 1286 Isolated From Caatinga Soil. J App Biol Biotech. 2016; 4 (04): 001-010. 